\title{
Heterogeneous Catalytic Ozonation of Phenol by a Novel Binary Catalyst of Fe-Ni/MAC
}

\author{
Yunlong Yang ${ }^{1}$, Xianwei Shi ${ }^{1}$, min Zhao ${ }^{2}$, Shuyi Chu ${ }^{3}$ and Jibo Xiao ${ }^{1,4, *}$ \\ 1 College of Life and Environmental Science, Wenzhou University, Wenzhou 325035, China; \\ ylyang@wzu.edu.cn (Y.Y.); xwshi1995@126.com (X.S.) \\ 2 National and Local Joint Engineering Research Center of Ecological Treatment Technology for Urban \\ Water Pollution, Wenzhou University, Wenzhou 325035, China; zhaomin@wzu.edu.cn \\ 3 Wenzhou Academy of Agricultural Sciences, Wenzhou 325006, China; chusy@zafu.edu.cn \\ 4 Wenzhou Chuangyuan Environment Technology Co. Ltd., Wenzhou 325036, China \\ * Correspondence: jbxiao@wzu.edu.cn
}

Received: 28 July 2020; Accepted: 21 September 2020; Published: 1 October 2020

\begin{abstract}
Iron-nickel supported on modified active carbon (Fe-Ni/MAC) was prepared and characterized by XRD, SEM, XPS and EDS, followed by evaluating the practicability of Fe-Ni/MAC in treating real wastewater with a high concentration of phenol. Results showed that the optimal conditions for catalytic ozonation obtained by response surface methodology (RSM) were catalyst $10 \mathrm{~g} / \mathrm{L}$, ozone $68 \mathrm{mg} / \mathrm{L}$, pH 9 and reaction time $90 \mathrm{~min}$. Fe-Ni alloy and $\mathrm{NiFe}_{2} \mathrm{O}_{4}$ were demonstrated to be the dominant active species involved in catalytic reaction. The Fe-Ni/MAC catalyst can be reused six times with a satisfactory performance and little leaching of metal ions. Although some radicals like $\cdot \mathrm{OH}$ and $\cdot \mathrm{O}_{2}^{-}$functioned well, singlet oxygen $\left({ }^{1} \mathrm{O}_{2}\right)$ was regarded as the most important radical in the Fe-Ni/MAC process. Most noticeably, the fluorescence excitation emission matrices (EEMs) certified that as much as $1243 \mathrm{mg} / \mathrm{L}$ phenol in the real wastewater was completely degraded, which made Fe-Ni/MAC a fairly practical catalyst.
\end{abstract}

Keywords: catalytic ozonation; phenol degradation; binary catalyst; Fe-Ni/MAC; wastewater

\section{Introduction}

Phenol and phenolic compounds have been found in a variety of industrial wastewaters, such as those from petroleum refining, petrochemical, pharmaceutical, plastic and pesticide chemical industries [1]. These pollutants are not only hazardous to the environment but also harmful for human health, even at low concentrations [2], hence, they have been listed on the priority list of EPA (Environment Protection Agency) since 1976 [3]. In consideration of their strong toxicity, they must be processed prior to discharge into receiving waters. For this purpose, various related technologies have been developed. Of them, advanced oxidation processes (AOPs) are supposed to be the most suitable processes, as AOPs are characterized by low operation cost, no need for special equipment, less energy consumption and high conversion of the organic pollutants [4-6].

Despite being an effective method to degrade toxic organics in aqueous solution, homogeneous catalytic oxidation using $\mathrm{H}_{2} \mathrm{O}_{2}$ and ferrous iron as oxidizing agents would take a long time to separate catalysts. Additionally, most of the dissolved metal catalysts could exert an adverse effect on the environment. These disadvantages, however, could be overcome by using heterogeneous catalysts since they are easily recoverable and reusable [7], and thus heterogeneous catalytic ozonation has been used extensively to remove phenol and its derivatives from wastewater, including $\mathrm{ZnAl}_{2} \mathrm{O}_{4}$ as a novel high surface area ozonation catalyst [8], Mn-Co-Fe exhibited the highest catalytic activity and stability for the mineralization of p-nitrophenol [9], magnetic carbonaceous nanocomposites were applied for the 
heterogeneous ozonation of 2, 4-dinitrophenol [10], $\mathrm{Pt} / \mathrm{Al}_{2} \mathrm{O}_{3}$ was used for the treatment of a simulated phenolic effluent [11], $\beta-\mathrm{MnO}_{2}$ nanowires showed good separability and remarkable catalysis for the degradation of phenol [12], $\mathrm{Fe}-\mathrm{Mn}-\mathrm{Cu} / \gamma-\mathrm{Al}_{2} \mathrm{O}_{3}$ was used to mineralize phenol wastewater [13] and $\mathrm{AC} /$ nano- $\mathrm{Fe}_{3} \mathrm{O}_{4}$ composites were capable of degrading phenol in industrial wastewater $[14,15]$.

Transition metals and their alloys have been reported to obtain a high surface area and excellent catalytic activity with exceptional mechanical strength [16], of which Ni-based catalysts are generally employed, owing to their superior catalytic activity and low cost. Meanwhile, to further promote the catalytic activity of Ni-based catalysts, various promoters were developed, among which Fe, a VIII group metal, has been referred to as an active material and was combined with $\mathrm{Ni}$ to form a binary catalyst of Fe-Ni. Due to high activity, good redox properties and low cost, the Fe-Ni binary catalysts have been used widely in many fields like hydrogenation reactions [17], hydrogen production [18], pollutant degradation [19], substitute natural gas production [20], carbon nanotube synthesis [16,21] and urea electrolysis [22]. Nevertheless, to the best of our knowledge, almost no studies on the heterogeneous catalytic ozonation of phenol by Fe-Ni/MAC have been found so far.

In this work, a binary catalyst, iron-nickel supported on modified active carbon (Fe-Ni/MAC), was synthesized via the co-precipitation method. As one of the most ubiquitous industrial wastewater contaminants, phenol was selected to assess the catalytic ozonation activity of Fe-Ni/MAC. However, there are a variety of factors affecting the catalyst's efficacy, indicative of a need to optimize related parameters. A statistical tool known as response surface methodology (RSM) was used to explore the influence of an independent variable or combination of both independent variables and dependent variables [23]. Therefore, the preparation procedure was firstly optimized by RSM to gain optimal preparation conditions, following which the structure, morphology and surface property of the catalyst were investigated through different characterization methods. Additionally, the catalyst reusability was tested and catalytic mechanisms were analyzed by using ascorbic acid, tert-butyl alcohol and L-histidine. Moreover, the catalytic ozonation capability of Fe-Ni/MAC to degrade the real phenol wastewater was evaluated.

\section{Results and Discussion}

\subsection{Optimization of Fe-Ni/MAC Fabrication}

The calcined temperature, $\mathrm{Fe} / \mathrm{Ni}$ and calcined time were optimized through RSM based on a Box-Behnken design (BBD), during which the removal efficiency (RE) of phenol was chosen as the response value, and the detailed design, together with the corresponding response, are displayed in Table S3. For the purpose of depicting the relationship between phenol RE (Y) and test variables (A: calcined temperature, B: iron/nickel ratio and C: calcined time), all data went through multiple regression analysis to gain the following polynomial equation:

$$
\begin{aligned}
& \mathrm{Y}=83.91-3.51 \times \mathrm{A}-4.12 \times \mathrm{B}-0.9093 \times \mathrm{C}+1.71 \times \mathrm{AB}+0.345 \times \mathrm{AC}+1.62 \\
& \times \mathrm{BC}-6.23 \times \mathrm{A}^{2}-5.04 \times \mathrm{B}^{2}-2.91 \times \mathrm{C}^{2}
\end{aligned}
$$

Table 1 presents the ANOVA results of the quadratic model. The large F value indicates that most of the variation in the response can be explained by the regression model equation. The associated $\mathrm{p}$-value is used to judge whether $\mathrm{F}$ is large enough to indicate statistical significance or not [24]. In this case, the model F-value was evaluated as 147.54, indicating that the resultant quadratic model is extremely significant. A $p$-value less than 0.05 shows that the model terms are significant, hence the calcined temperature, $\mathrm{Fe} / \mathrm{Ni}$ ratio, calcined time and their quadratic terms had a critical effect on the $\mathrm{RE}$ of phenol $(p<0.05)$. Evidently, among all the factors, the $\mathrm{Fe} / \mathrm{Ni}$ ratio was a dominating factor since its sum of squares (135.63) was higher than that of temperature (89.21) and time (5.99). The same conclusion can be also drawn from the 3D response surface and 2D contour plots (see the following section). For the mutual interaction terms, the $p$-value of $\mathrm{AC}$ was found to be 0.3659 , indicative of no striking interaction between calcined temperature and time. Generally, an adequate level of precision 
measures the signal to noise ratio, and a ratio greater than 4 is desirable [25]. As such, the ratio of 32.871 in the obtained quadratic model revealed a fairly adequate signal for the model that can be used to navigate the design space. Moreover, the determination coefficient $R^{2}$ and adjusted determination coefficient $R^{2}$ (adj) from the model were 0.9948 and 0.9880 , respectively, further confirming a high significance of the obtained model. Additionally, an $\mathrm{R}^{2}$ value higher than 0.9 could be regarded as having a high correlation. Taken together, it is quite reasonable to use the above quadratic function to analyze the trends in the response.

Table 1. ANOVA of the regression model obtained from response surface methodology (RSM).

\begin{tabular}{cccccc}
\hline Source & Sum of Squares & Degrees of Freedom & Mean Square & F-Value & $p>$ F \\
\hline Model & 676.63 & 9 & 75.18 & 147.54 & $<0.0001$ \\
A & 89.21 & 1 & 89.21 & 175.08 & $<0.0001$ \\
B & 135.63 & 1 & 135.63 & 266.17 & $<0.0001$ \\
C & 5.99 & 1 & 5.99 & 11.76 & 0.0110 \\
AB & 13.12 & 1 & 13.12 & 25.74 & 0.0014 \\
AC & 0.4761 & 1 & 0.4761 & 0.9343 & 0.3659 \\
BC & 11.68 & 1 & 11.68 & 22.92 & 0.0020 \\
$A^{2}$ & 163.34 & 1 & 163.34 & 320.56 & $<0.0001$ \\
$B^{2}$ & 56.30 & 1 & 56.30 & 110.50 & $<0.0001$ \\
$C^{2}$ & 35.74 & 1 & 35.74 & 70.14 & $<0.0001$ \\
Residual & 3.57 & 7 & 0.5096 & & \\
Lack of fit & 2.45 & 3 & 0.8172 & 2.93 & 0.1629 \\
Pure error & 1.12 & 4 & 0.2788 & & \\
Total & 680.20 & 16 & & &
\end{tabular}

The obtained Equation (1) was employed to visualize the effects of experimental parameters on the phenol RE, the 3D response surface and 2D contour plots, which are separately depicted in Figure 1 and Figure S2. Specifically, the relationships between A and B (Figure 1a) and between B and C (Figure 2b), as well as between A and C (Figure 1c), suggested well-defined optimum conditions, as they all showed conspicuous convexity. The $2 \mathrm{D}$ contour plots are graphic representations of relationships between response and experimental variables that can be used for determining the optimum conditions. Therefore, on the basis of these figures, the order of the three independent variables affecting the RE of phenol should be as follows: Fe/Ni ratio $>$ calcined temperature $>$ calcined time, since the phenol $\mathrm{RE}$ increased and then deceased with the $\mathrm{Fe} / \mathrm{Ni}$ ratio rising at a fixed temperature, manifesting that $\mathrm{Fe} / \mathrm{Ni}$ ratio and temperature play a decisive role in the catalytic ozonation of phenol. The $2 \mathrm{D}$ contours coupled with the $p$-value (Table 1) showed that there was an apparent interaction between the $\mathrm{Fe} / \mathrm{Ni}$ ratio and temperature, as well as $\mathrm{Fe} / \mathrm{Ni}$ ratio and time, whereas no obvious interaction of temperature and time was observed. According to the equation model, the optimal conditions of Fe-Ni/MAC fabrication were a calcined temperature of $431.885^{\circ} \mathrm{C}$, an $\mathrm{Fe} / \mathrm{Ni}$ ratio of 0.945 and a calcined time of $3.667 \mathrm{~h}$. The corresponding predicted maximum phenol RE was $85.764 \%$.

With the optimal parameters mentioned above, the binary catalyst was synthesized and afterwards used to degrade phenol to verify the quadratic equation. As seen in Figure S3, the RE of phenol went up gradually with time and finally reached $85.99 \%$ at $60 \mathrm{~min}$, which was undoubtedly in good conformity with the predicted maximal value of $85.764 \%$ in the model. As a consequence, the optimized preparation procedure could provide a more suitable environment for the catalytic activity of $\mathrm{Fe}-\mathrm{Ni} / \mathrm{MAC}$, thus benefiting the phenol degradation. 

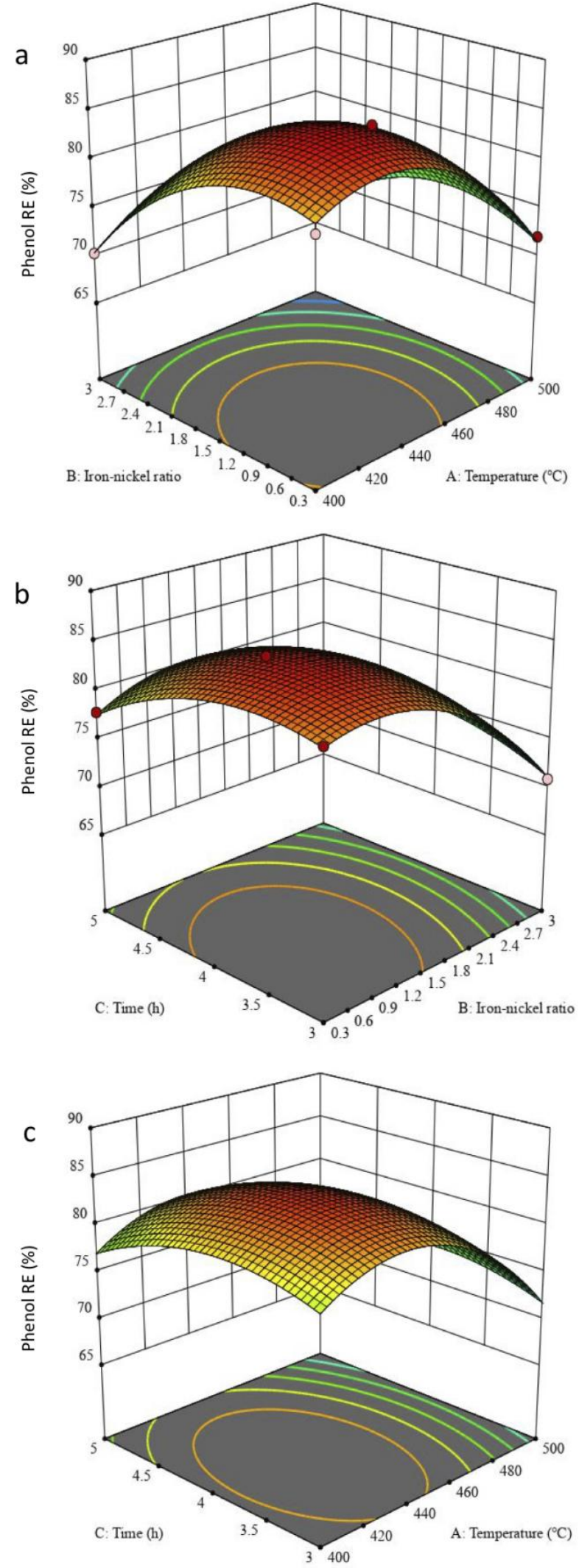

Figure 1. Response surface of phenol removal efficiency (RE) as a function of temperature and iron-nickel ratio (a), iron-nickel ratio and time (b) and temperature and time (c). 

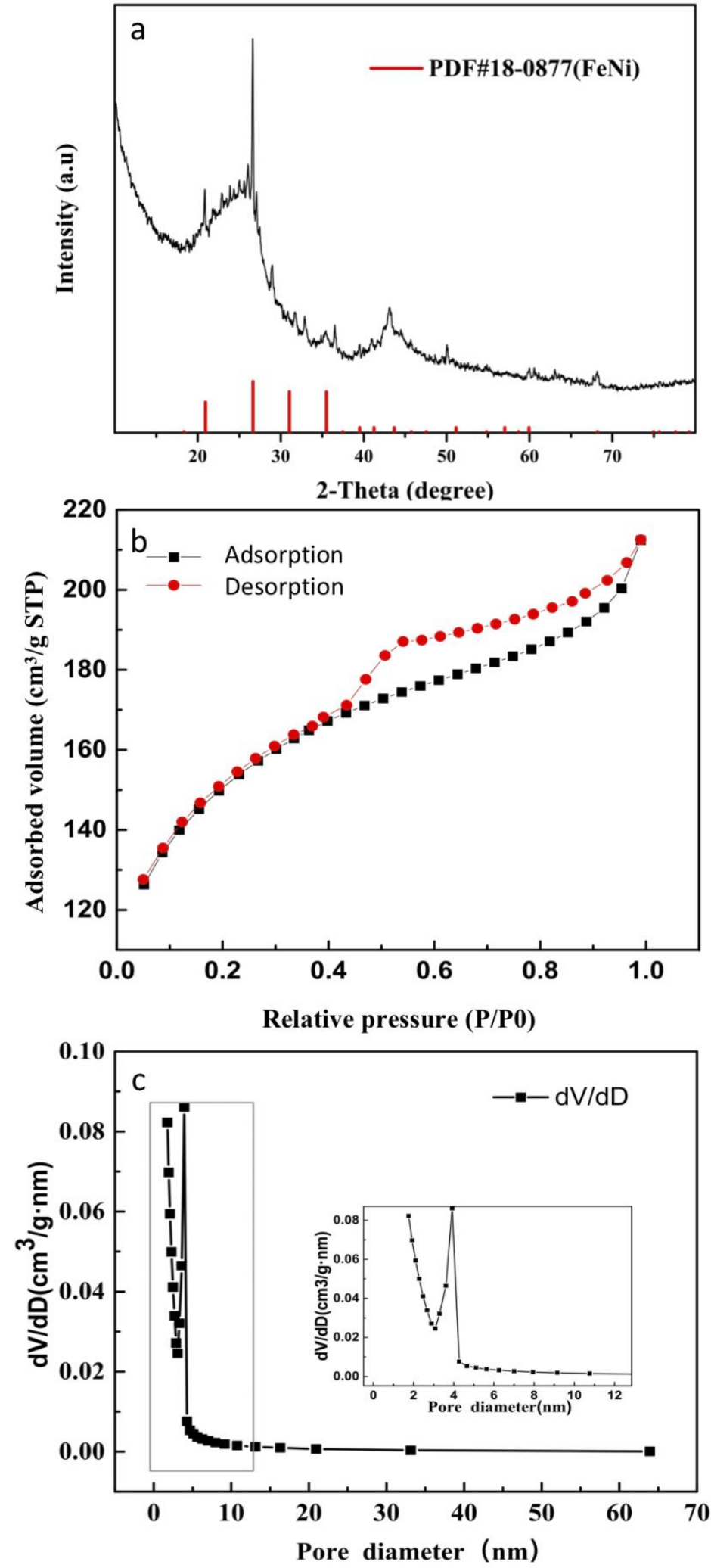

Figure 2. XRD pattern (a), nitrogen adsorption-desorption isotherms (b) and pore size distribution of the fresh Fe-Ni/MAC (c). 


\subsection{Characterization of $\mathrm{Fe}-\mathrm{Ni} / \mathrm{MAC}$}

Figure 2a presents XRD patterns for the binary catalyst of Fe-Ni/MAC under the optimal conditions (calcined temperature: $431.8^{\circ} \mathrm{C}$; calcined time: $2 \mathrm{~h} ; \mathrm{Fe} / \mathrm{Ni}$ ratio: 0.946 ). The diffraction peaks at $2 \theta=20.939,26.667,31.037,35.509,37.473,39.509,41.245,43.692,45.76$ and 47.568 were attributed to the crystalline Fe-Ni alloy (JCPDS No. 18-0877), while the $2 \theta$ values at $26.603,42.717,43.45$ and 44.669 were assigned to the carbon support (JCPDS No. 26-1076). In addition, some other peaks with the $2 \theta$ values falling into 45-50 and 65-70 also appeared, which were presumed to be $\mathrm{NiFe}_{2} \mathrm{O}_{4}$ (see XPS data). These results were almost distinct from those in a previous report, in which no distinguishable peak was observed corresponding to the crystalline Ni-Fe alloy when the catalyst was calcined at $500^{\circ} \mathrm{C}$ for $2 \mathrm{~h}$ [17]. This phenomenon was probably due to the following two points: (1) the different catalyst support would create different crystalline structures and (2) the $\mathrm{Ni}_{x} \mathrm{Fe}_{y}$ alloy can be formed only in a certain range of $\mathrm{Ni} / \mathrm{Fe}$ ratio [20]. That is to say, the Fe/Ni ratio gained by RSM in the current study was quite favorable for the formation of crystalline $\mathrm{Fe}-\mathrm{Ni}$ alloy under our experimental conditions.

The nitrogen adsorption-desorption isotherms for the fresh Fe-Ni/MAC were performed and the results are displayed in Figure $2 \mathrm{~b}$. Evidently, with the relative pressure elevation, the catalyst adsorption volume increased and the curve of desorption was higher than that of adsorption to form a complete loop when the relative pressure varied from 0.4 to 1.0. Thereby, the $\mathrm{N}_{2}$ isotherms corresponded to a type IV isotherm with the hysteresis loop being type $\mathrm{H}_{4}$, in accordance with the International Union of Pure and Applied Chemistry (IUPAC) [26]. For the pore size distribution, a conspicuous peak at $4 \mathrm{~nm}$ could be seen (Figure 2c), which is consistent with the mesoporous range associated with the isotherm, further proving type $\mathrm{H}_{4}$ as catalysts. Likewise, an average pore radius of $2.45 \mathrm{~nm}$ for Fe-Ni/MAC, listed in Table 2, also confirmed the above conclusion. With no doubt, ample mesoporous structures would give rise to a sufficient catalyst-pollutant contact to ensure an efficient reaction of catalytic ozonation. Apart from the mesoporous structure, a BET surface area of $502.68 \mathrm{~m}^{2} / \mathrm{g}$ and an average pore volume of $0.31 \mathrm{~cm}^{3} / \mathrm{g}$ were observed, which were comparable to some other relevant catalysts $[15,27]$.

Table 2. Surface area, pore volume and radius of the fresh Fe-Ni/MAC.

\begin{tabular}{cccc}
\hline BET Surface Area $\left(\mathrm{m}^{2} / \mathrm{g}\right)$ & Langmuir Surface Area $\left(\mathrm{m}^{2} / \mathrm{g}\right)$ & Average Pore Volume $\left(\mathrm{cm}^{3} / \mathrm{g}\right)$ & Average Pore Radius $(\mathrm{nm})$ \\
\hline 502.68 & 887.87 & 0.31 & 2.45 \\
\hline
\end{tabular}

The morphology of the developed catalysts after calcination was examined using SEM-EDS, and the corresponding results are exhibited in Figure 3. As observed in the figure, the surface of active carbon on which there were a few small holes was relatively smooth (Figure 3a), whereas the binary catalyst of Fe-Ni/MAC possessed a rougher surface coupled with a highly developed pore structure, and metal particles distributed uniformly without aggregation (Figure $3 b$ ), all of which are essential for the activity of a catalyst. A similar phenomenon could be found in a previous study where the metal particles on the catalyst support of $\mathrm{Al}_{2} \mathrm{O}_{3}$ were uniform in shape with a diameter of several tens of nanometers [20]. To further illustrate the distribution of $\mathrm{Fe}$ and $\mathrm{Ni}$, elemental mapping was conducted to characterize the binary catalyst, as shown in Figure 3c-f. Clearly, the homogeneous distribution of both Fe and $\mathrm{Ni}$ was obtained, which could favor their close and effective contact to form bimetallic corrosion cells, and speed up the electron transfer of galvanic corrosion [28], thus promoting pollutant degradation.

The state of elements included in Fe-Ni/MAC was determined by XPS (Figure 4), whereby the peaks of $\mathrm{O}, \mathrm{C}, \mathrm{Fe}$ and $\mathrm{Ni}$ were found (Figure $4 \mathrm{a}$ ). In Figure $4 \mathrm{~b}$, there are three main peaks observed at $711.0 \mathrm{eV}, 714.0 \mathrm{eV}$ and $724.2 \mathrm{eV}$ that were ascribed to $\mathrm{Fe}$ (III) presenting in the form of $\mathrm{NiFe}_{2} \mathrm{O}_{4}$ [29], while the four peaks respectively located at the binding energy of 856.2, 861.8, 873.7 and $879.8 \mathrm{eV}$ can be seen in Figure 4c, which confirmed the existence of $\mathrm{Ni}$ (II) [30]. In contradiction to the XRD results (Figure 2), however, both metallic $\mathrm{Fe}$ and Ni were not detected, the reason for which was the fact that there is an interaction between metallic $\mathrm{Ni}$ and $\mathrm{Fe}$, leading to the binding energies of metallic $\mathrm{Ni}$ and $\mathrm{Fe}$ 
being higher than those of the standard XPS data [31], which likely suggests that the sample bulk phase is mostly an alloy phase and the surface is the oxidized species [31]. In addition, at least one regular alloy with a $\mathrm{FeNi}_{3}$ composition is known, and irregular bulk alloys with the compositions $\mathrm{NiFe}, \mathrm{Ni}_{3} \mathrm{Fe}_{2}$ and $\mathrm{Ni}_{2} \mathrm{Fe}$ have also been reported [27]. Thus, taking the XRD results into account, this phenomenon is consistent with a former study showing that bimetallic systems most likely contain a range of metal particles with somewhat different Fe-Ni ratios [27]. Figure 4d depicts the XPS spectra of the O 1s core level, in which the peaks with binding energy of $530.4 \mathrm{eV}, 531.6 \mathrm{eV}$ and $532.7 \mathrm{eV}$ are indicative of the lattice oxygen, hydroxide oxygen and water oxygen [32,33], respectively. These results demonstrated that $\mathrm{Fe}-\mathrm{Ni}$ alloy and $\mathrm{NiFe}_{2} \mathrm{O}_{4}$ were the dominant active species involved in the catalytic reaction.

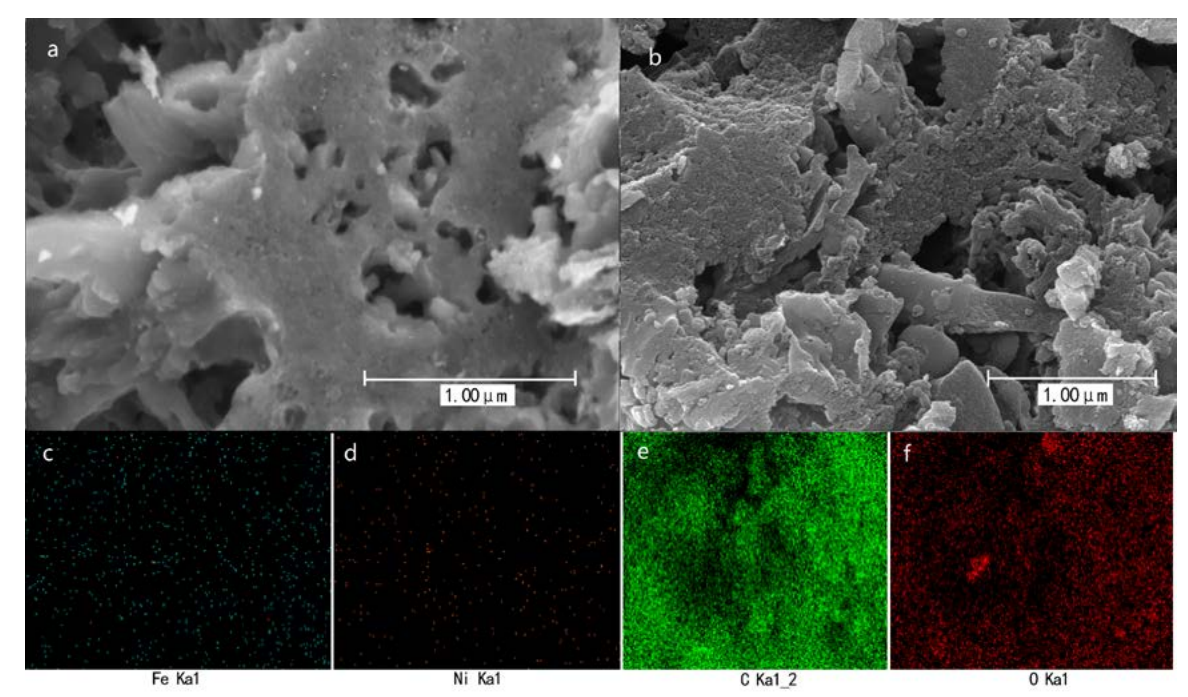

Figure 3. SEM micrographs: active carbon (a); Fe-Ni/MAC (b) and element mapping micrographs: iron (c); nickel (d); carbon (e); oxygen (f).
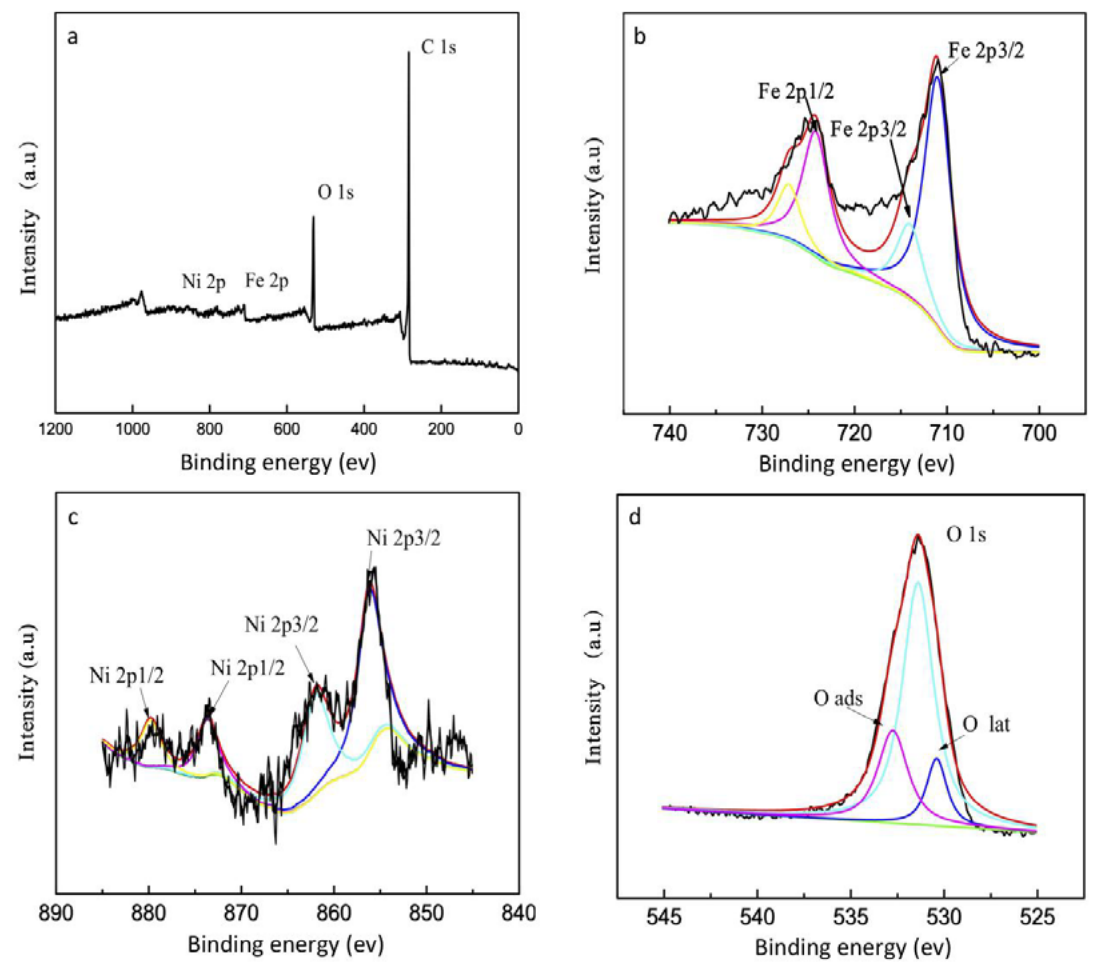

Figure 4. X-ray photoelectron spectroscopy (XPS) spectra of full scale (a), Fe 2p (b), Ni 2p (c) and O 1s (d) for the Fe-Ni/MAC catalyst. 


\subsection{Catalytic Performance of Fe-Ni/MAC}

\subsubsection{Key Parameters Affecting the Catalytic Performance}

In order to obtain optimal conditions, effects of key factors, including catalyst dosage, ozone concentration, initial $\mathrm{pH}$ and reaction time on the catalytic performance, were assessed through single-factor experiments (Figure 5). It is clear that the phenol RE rose dramatically from $61.94 \%$ at a catalyst dosage of $0.5 \mathrm{~g} / \mathrm{L}$ to $94.25 \%$ at a catalyst dosage of $10 \mathrm{~g} / \mathrm{L}$, and then dropped to no more than $90 \%$ when the catalyst dosage was $20 \mathrm{~g} / \mathrm{L}$ (Figure 5a), suggesting that (1) the increase in catalyst dosage could give a greater total number of active sites to facilitate the decomposition of ozone and produce more radical groups, (2) increasing the catalyst dosage could improve the molecule ozone transfer into the reaction solution [34] and (3) a higher catalyst dosage generated excess radical groups that may undergo recombination reactions or react with ozone to result in a decline in phenol RE [35]. Accordingly, a $10 \mathrm{~g} / \mathrm{L}$ catalyst dosage was used in the following experiments.

$$
\begin{gathered}
\mathrm{HO}+\mathrm{HO} \rightarrow \mathrm{H}_{2} \mathrm{O}_{2} \\
\mathrm{HO}+\mathrm{O}_{3} \rightarrow \mathrm{O}_{2}+\mathrm{HO}_{2}
\end{gathered}
$$
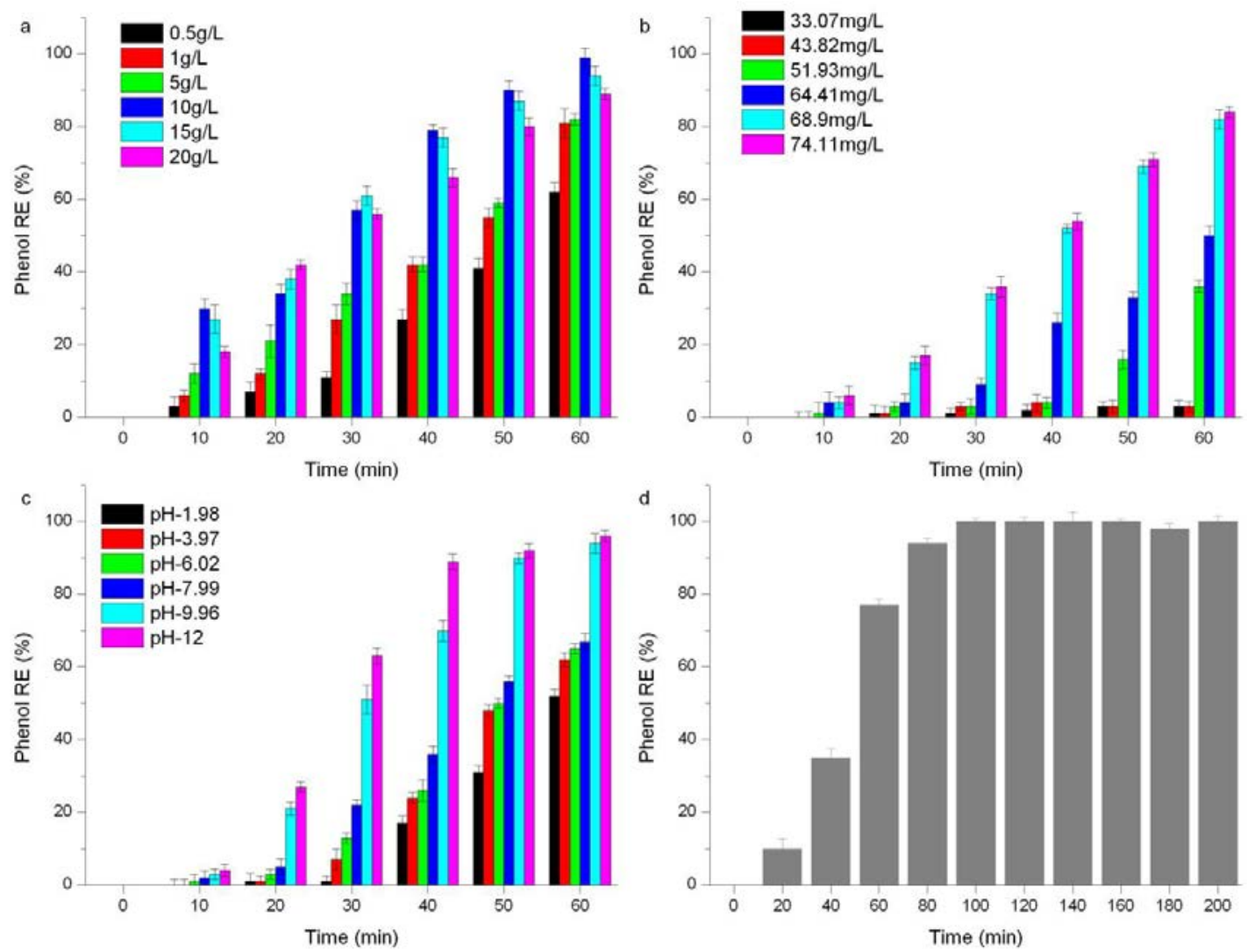

Figure 5. Effect of catalyst dosage (a), ozone concentration (b), initial $\mathrm{pH}(\mathbf{c})$ and reaction time (d) on the phenol degradation.

A gradient of different ozone concentrations (33.07, 43.82, 51.93, 64.41, 68.90 and $74.11 \mathrm{mg} / \mathrm{L}$ ) exerted an obvious influence on the phenol RE (Figure $5 b$ ). For the low concentrations of $33.07 \mathrm{mg} / \mathrm{L}$ and $43.82 \mathrm{mg} / \mathrm{L}$, phenol was hardly removed within $60 \mathrm{~min}$, and subsequently the phenol RE increased to $36.39 \%$ when ozone was at $51.93 \mathrm{mg} / \mathrm{L}$, indicating that ozone was still too low to degrade phenol effectively in a short time. When ozone was at $68.90 \mathrm{mg} / \mathrm{L}$, the phenol RE climbed to $83.87 \%$, yet the further increase in ozone made no remarkable contribution to the phenol degradation since the 
ozone concentration in the liquid phase approached its maximum value at a fixed temperature [36]. As a consequence, the ozone concentration of $68.90 \mathrm{mg} / \mathrm{L}$ was selected as the optimal value in the following study.

Figure $5 \mathrm{c}$ shows the effect of initial $\mathrm{pH}$ on the phenol degradation. As illustrated in the figure, the range of $\mathrm{pH}$ could be divided into two parts: part I with a $\mathrm{pH}$ from 1.98 to 7.99 and part II consisting of $\mathrm{pH}$ between 9.96 and 12.00. In part I, the phenol RE increased from $51.99 \%$ to $67.19 \%$ within 60 min when the $\mathrm{pH}$ was elevated from 1.98 to 7.99 , manifesting that the phenol degradation was not affected markedly in this $\mathrm{pH}$ range, whereas the phenol $\mathrm{RE}$ soared to $96.08 \%$ at $\mathrm{pH} 12.0$ in part II but no significant difference was found between $\mathrm{pH} 9.96$ and 12.00, revealing that a relatively high $\mathrm{pH}$ would contribute to the enhancement of phenol RE. A previous study reported that catalytic ozonation could be improved with the increment of initial solution $\mathrm{pH}$, and the high removal efficiency was obtained under alkaline conditions [34], which was in agreement with the result observed in this study. Notwithstanding, as presented in Figure $5 \mathrm{c}$, the $\mathrm{pH}$ beyond a certain value could not improve pollutant degradation greatly, as the catalyst is negatively charged at higher $\mathrm{pH}$ values, therefore creating repulsive electrostatic interactions between pollutants and the catalyst surface that may inhibit surface reactions [11].

Figure $5 d$ exhibits the effect of reaction time on the phenol RE. As expected, the RE increased with an increase in reaction time, and the highest phenol RE was found to be $99.98 \%$ at $100 \mathrm{~min}$. This phenomenon might be due to small molecular substances generated during the reaction that exerted a negative impact on the degradation of phenol. Overall, based on the results of single-factor experiments, the optimal conditions of catalytic ozonation by Fe-Ni/MAC were: catalyst $10 \mathrm{~g} / \mathrm{L}$, ozone $68 \mathrm{mg} / \mathrm{L}, \mathrm{pH} 9$ and reaction time $90 \mathrm{~min}$, which were adopted in subsequent experiments.

\subsubsection{Reusability and Stability of Fe-Ni/MAC Catalyst}

From a practical point of view, durability is an extremely important property for prepared catalysts. Regarding durability, however, there are two competing conclusions. One is that the contaminant removal is improved after reuse, due to the modification of chemical functional groups on the catalyst surface by ozonation and the rise in both the pore volumes and the specific surface areas [37-39]. The other is that ozonation reduces catalytic properties of activated carbon due to a decrease in basic groups and an increase in the number of oxygenated surface functional groups, such as hydroxyl and carboxylic acid groups and nitro aromatic compounds [40]. While in the present study a slight decline could be seen in the catalytic activity of the Fe-Ni/MAC catalyst after reuse (Figure 6a), which seemed to be in accordance with the above second conclusion, the phenol RE still maintained a level of more than $86.57 \%$ after six cycles, verifying that the binary catalyst of Fe-Ni/MAC is suitable for the practical application. With respect to the catalyst stability, the leaching of $\mathrm{Fe}^{3+}$ and $\mathrm{Ni}^{2+}$ after recycling experiments was measured. As observed in Figure $6 \mathrm{~b}$, the levels of $\mathrm{Fe}^{3+}$ and $\mathrm{Ni}^{2+}$ leached from Fe-Ni/MAC after each cycle were below $3 \mathrm{mg} / \mathrm{L}$ and $0.5 \mathrm{mg} / \mathrm{L}$, respectively, indicating that $\mathrm{Fe}$ on the catalyst surface was more prone to being dissolved than Ni during the catalytic ozonation process. However, the level of leaching of these two ions was so low that no secondary pollution could be caused. Undoubtedly, it can be concluded that the Fe-Ni/MAC process would be feasible and cost effective on the basis of both the reusability and stability results.

\subsubsection{Real Phenol-Containing Wastewater Treatment by Fe-Ni/MAC}

Real phenol-containing wastewater was used to investigate deeply the catalyst practicability. In this section, the characterization and analysis of wastewater were conducted by the fluorescence excitation emission matrices (EEMs), for this method is characterized by high detection sensitivity and easy operation. Figure S4 displays the 3D excitation emission matrices of the real phenol-containing wastewater before and after the treatment by Fe-Ni/MAC. It is fairly clear that a peak located at Ex/Em: $272 \mathrm{~nm} / 298 \mathrm{~nm}$, indicative of phenol [41], existed in the real wastewater before the reaction (Figure S4a), but it was almost totally reduced after the reaction and a new peak that might be attributed to the 
intermediate of phenol degradation was observed (Figure S4b). A study reported that a more than 90\% reduction of phenolic compounds in kraft pulp mill effluent was achieved when ozonation was preceded by chemical coagulation or powdered activated carbon adsorption [42]. Comparably, the binary catalyst of Fe-Ni/MAC prepared in our study would be more applicable and efficient when treating the real phenol-containing wastewater since the phenol concentration was as high as $1243 \mathrm{mg} / \mathrm{L}$ (Table S2) and no other methods were incorporated. Nevertheless, the potential intermediates produced during the phenol degradation which likely adversely affected the deep treatment of wastewater were not determined, and therefore more studies should be performed to address these problems in the future.
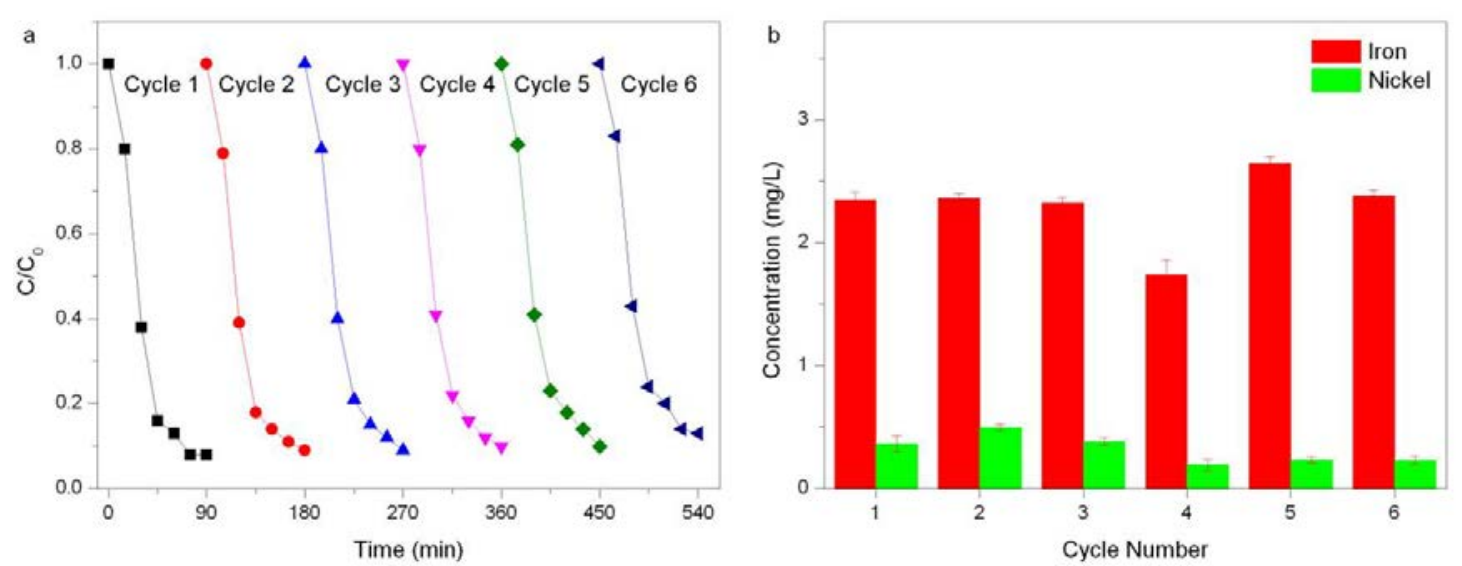

Figure 6. Recycling experiments of Fe-Ni/MAC (a) and corresponding leaching of iron and nickel (b) performed under optimal conditions: catalyst $10 \mathrm{~g} / \mathrm{L}$, ozone $68 \mathrm{mg} / \mathrm{L}, \mathrm{pH} 9$ and reaction time $90 \mathrm{~min}$.

\subsection{Investigation of Active Oxidative Species}

As we know, the determination of active oxidative species was necessary and critical as they can enhance catalytic activity and play an indispensable part in the confirmation of reaction pathways and catalytic mechanisms in catalytic ozonation [8]. Accordingly, the catalytic mechanism of the $\mathrm{Fe}-\mathrm{Ni} / \mathrm{MAC}$ process was explored gradually through various radical scavengers, including ascorbic acid (AA), tert-butyl alcohol (TBA) and histidine (His), and the results are illustrated in Figure 7. As predicted, some radicals were generated in the catalytic ozonation process because the phenol RE fell from $91.77 \%$ to $68.41 \%$ when AA rose from 0.5 to $20 \mathrm{mmol}$ (Figure $7 \mathrm{a}$ ). AA is usually used to scavenge $\mathrm{HO}_{2}, \mathrm{OH}$ and $\mathrm{O}_{2}^{-}$owing to its high reducibility [43], hence, a decrease of $28.93 \%$ for the phenol RE proved the existence of active oxidative species.

It was reported that the reaction rate constants of TBA with hydroxyl radicals and ozone were $5.0 \times 10^{8} \mathrm{M}^{-1} \mathrm{~s}^{-1}$ and $3.0 \times 10^{-3} \mathrm{M}^{-1} \mathrm{~s}^{-1}$, respectively [44], demonstrating that TBA is a strong hydroxyl radical scavenger. Thus, TBA was utilized to assess the role hydroxyl radicals play in catalytic ozonation, and the corresponding results are presented in Figure $7 \mathrm{~b}$. Clearly, the addition of TBA did not remarkably suppress the degradation of phenol, implying that only a certain number of hydroxyl radicals were generated in the reaction system.

In light of the results showed in Figure 7a,b, the phenol degradation was not inhibited entirely, indicating that some other radicals should take effect apart from hydroxyl radicals. As such, His was added to the reaction system as it has been shown to scavenge both hydroxyl radicals and singlet oxygen $\left({ }^{1} \mathrm{O}_{2}\right)$ [45]. It can be seen from Figure $7 \mathrm{c}$ that the more His, the greater the inhibition to phenol removal. In particular, the phenol RE declined to $17.74 \%$ when His was $10 \mathrm{mmol}$, suggesting that the main reason for the degradation of phenol was due to singlet oxygen $\left({ }^{1} \mathrm{O}_{2}\right)$ rather than hydroxyl radicals $(\cdot \mathrm{OH})$. In consideration of the conversion of $\cdot \mathrm{O}_{2}^{-}$to ${ }^{1} \mathrm{O}_{2}$ in a short time, it can be concluded that although some radicals like $\cdot \mathrm{OH}$ and $\cdot \mathrm{O}_{2}^{-}$did function, singlet oxygen $\left({ }^{1} \mathrm{O}_{2}\right)$ was regarded as the most important radical in the $\mathrm{Fe}-\mathrm{Ni} / \mathrm{MAC}$ process. 

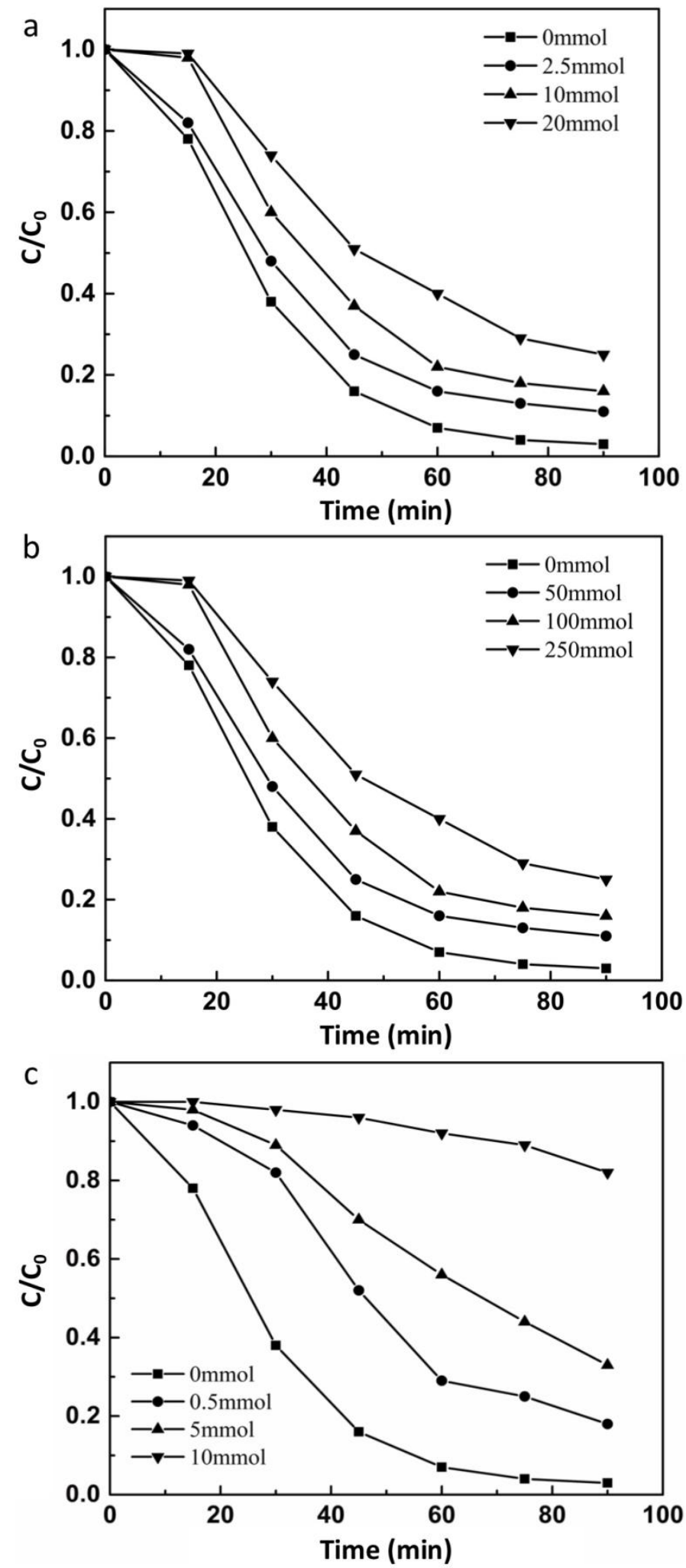

Figure 7. Effect of AA (a), TBA (b) and His (c) on the phenol removal by Fe-Ni/MAC.

\subsection{Possible Mechanisms Discussion}

According to the above analysis and the present literature, the possible mechanisms for the removal of phenol by the Fe-Ni/MAC process was summarized as Equations (4)-(6). More specifically, after the addition of $\mathrm{Fe}-\mathrm{Ni} / \mathrm{MAC}, \mathrm{H}_{2} \mathrm{O}$ was strongly adsorbed on the surface of Fe-Ni/MAC and 
dissociated into $\mathrm{OH}^{-}$and $\mathrm{H}^{+}$, forming the surface hydroxyl groups. Afterwards, the adsorbed ozone on the catalyst surface interacted with surface hydroxyl groups to give rise to $\mathrm{OH}$ and $\cdot \mathrm{O}_{2}^{-}\left({ }^{1} \mathrm{O}_{2}\right)$. Then, the resultant radicals, especially ${ }^{1} \mathrm{O}_{2}$, took part in the degradation of phenol. In general, it is believed that ozone adsorbed on the surface is indispensable and subsequent transformation to active oxidative species is thought of as the main mechanism of pollutant removal by catalytic ozonation, yet various factors are involved in this process. For instance, the enhanced interfacial electron transfer resulted in the higher catalytic activity of $\mathrm{NiFe}_{2} \mathrm{O}_{4}-\mathrm{H}$ nanocatalysts [46], and the textural and chemical surface properties of activated carbon might have impacts on the ozonolysis process [47]. As a result, more detailed studies would be needed to elucidate the heterogeneous catalytic ozonation of phenol by the binary catalyst of Fe-Ni/MAC.

$$
\begin{gathered}
\mathrm{Ni}^{2+} \mathrm{Fe}_{2} \mathrm{O}_{4}-\mathrm{OH}^{-}+2 \mathrm{O}_{3} \rightarrow \mathrm{Ni}^{3+} \mathrm{Fe}_{2} \mathrm{O}_{4}+\cdot \mathrm{OH}+\mathrm{O}_{2}+2 \cdot \mathrm{O}_{2}^{-}\left({ }^{1} \mathrm{O}_{2}\right) \\
4 \mathrm{Ni}^{3+} \mathrm{Fe}_{2} \mathrm{O}_{4}+2 \mathrm{H}_{2} \mathrm{O} \rightarrow 4 \mathrm{Ni}^{2+} \mathrm{Fe}_{2} \mathrm{O}_{4}+\mathrm{O}_{2}+4 \mathrm{H}^{+} \\
\mathrm{Ni}^{2+} \mathrm{Fe}_{2} \mathrm{O}_{4}+\mathrm{H}_{2} \mathrm{O} \rightarrow \mathrm{Ni}^{2+} \mathrm{Fe}_{2} \mathrm{O}_{4}-\mathrm{OH}^{-}+\mathrm{H}^{+}
\end{gathered}
$$

\section{Materials and Methods}

\subsection{Preparation of Fe-Ni/MAC}

All chemical reagents were of analytical grade. To remove oil pollutants, the active carbon (Sinopharm, Shanghai, China) was soaked in $10 \% \mathrm{NaOH}$ solution for $24 \mathrm{~h}$ and then soaked in $5 \% \mathrm{HCl}$ solution for $4 \mathrm{~h}$ to eliminate metals as well as other impurities. After $2 \mathrm{~h}$ of water-boiling, the modified active carbon (MAC) was copiously washed with distilled water to neutral $\mathrm{pH}$ and dried at $105^{\circ} \mathrm{C}$ for further use.

Fe-Ni/MAC was synthesized by the co-precipitation method. In brief, a certain amount of MAC, ferric nitrate (Sinopharm, Shanghai, China) and nickel nitrate (Sinopharm, Shanghai, China) was mixed and oscillated for $4 \mathrm{~h}$ with a rotation speed of $130 \mathrm{rpm}$ at $35^{\circ} \mathrm{C}$. Following $\mathrm{pH}$ adjustment by a $5 \%$ ammonia solution, the resultant product was incubated for $4 \mathrm{~h}$ at $75^{\circ} \mathrm{C}$ and washed with distilled water until the solution was clear. Subsequently, the product was dried at $105^{\circ} \mathrm{C}$ for $2 \mathrm{~h}$, cooled to room temperature and finally placed into a muffle furnace (LICHEN, Shanghai, China). The furnace temperature was increased gradually at a rate of $2{ }^{\circ} \mathrm{C} / \mathrm{min}$ to $400{ }^{\circ} \mathrm{C}$ and was maintained for $2 \mathrm{~h}$.

\subsection{Characterization of Fe-Ni/MAC}

For X-ray diffraction patterns, a D8 X-ray diffractometer (Bruker AXS, Karlsruhe, German) with a filtered $\mathrm{Cu} \mathrm{K} \alpha$ radiation source, a voltage of $40 \mathrm{kV}$, a current of $40 \mathrm{~mA}$ and scanning at $2 \theta$ from 5 to $90^{\circ}$ was used to identify the composition and phase of the sample. To obtain specific surface area using the Brunauer-Emmett-Teller (BET) method, samples were degassed at $200{ }^{\circ} \mathrm{C}$ for $6 \mathrm{~h}$ under vacuum conditions before measurement and then $\mathrm{N}_{2}$ adsorption-desorption was measured on an ASAP2460 instrument (Micromeritics, Norcross, GA, USA). A Zeiss HD scanning electron microscope (SEM) equipped with an energy dispersive spectrometer (EDS) was utilized to observe the external morphology of samples. The surface oxidation states of samples were analyzed by X-ray photoelectron spectroscopy (XPS) (ThermoFisher Scientific, Waltham, MA, USA), and the high resolution spectra were calibrated by setting $\mathrm{C} 1 \mathrm{~s}$ at $284.8 \mathrm{eV}$.

\subsection{Experimental Procedures}

\subsubsection{Optimization for Catalyst Preparation}

According to our previous experimental results (data not shown), the calcined temperature, $\mathrm{Fe} / \mathrm{Ni}$ ratio and calcined time were screened for the most important factors affecting the activity of catalysts. Therefore, the response surface methodology (RSM) based on a Box-Behnken design (BBD) 
was employed to determine the optimal conditions of these three factors. Table S1 lists the detailed factors and levels adopted in the RSM based on a BBD. Both experimental designs and subsequent regression analysis of experimental data were conducted by Design Expert 11 (Stat-Ease, minneapolis, MN, USA). The F-value and $p$-value were used to assess the model significance, while the quality of the polynomial model equation was judged statistically on the basis of the coefficient of determination $R^{2}$. All experiments were repeated at least three times.

\subsubsection{Catalytic Activity Tests}

The catalytic ozonation of phenol was performed in an experimental system exhibited in Figure S1, which consisted of ozone generating devices, a catalytic reactor and exhaust collecting devices. The ozone generating devices with air as the feed gas were composed of an ozone generator, an oxygen generator and a gas rotameter controlling ozone concentration. The catalytic reactor with a total volume of $500 \mathrm{~mL}$ and a height to diameter ratio of 3:1, placed on a magnetic stirrer, was continuously injected with ozone through a flexible pipe from the bottom. The exhaust collecting devices were used to destroy the gas coming out of the reactor by traps previously filled with a concentrated potassium iodide solution [48].

In a typical experiment, $0.25 \mathrm{~g}$ catalyst and $250 \mathrm{~mL}$ of $300 \mathrm{mg} / \mathrm{L}$ phenol solution were added into the reactor with the ozone concentration and flow rate being $67.03 \mathrm{mg} / \mathrm{L}$ and $100 \mathrm{~mL} / \mathrm{min}$, respectively. The suspension was magnetically stirred throughout experiments. At given time intervals, samples of no more than $5 \mathrm{~mL}$ were withdrawn, following which $1 \mathrm{~mL}$ of $0.02 \mathrm{~mol} / \mathrm{L}$ sodium thiosulfate solution was added to quench the remaining ozone in the reaction solution. The effect of some factors, including $\mathrm{pH}$, catalyst dosage, ozone concentration and reaction time, was investigated in light of a one-factor method. For reusability, the catalyst was recovered after each run and was subsequently dried at $80^{\circ} \mathrm{C}$ for 120 min to obtain a "regenerated catalyst" that was used for the next run. This process was carried out six times under the same conditions. In the meantime, the suspension of each run was subjected to a measurement of Fe and Ni elements that might leach from the above "regenerated catalyst" because of repeated use.

In order to test the capability of degradation from engineering applications, the binary catalyst of Fe-Ni/MAC was also used to treat real phenol-containing wastewater under optimal conditions. The real wastewater came from an insulating material company (Yongchao, Dongguan, China), the quality of which is listed in Table S2.

\subsubsection{Radical Scavenging Experiments}

To identify the type of oxidation reaction, a few radical scavengers were used in the current study. As a highly reductive substance, ascorbic acid (AA) was employed to quench most kinds of reactive oxygen species (ROS) like $\mathrm{HO}_{2}, \mathrm{OH}$ and $\mathrm{O}_{2}^{-}$, while tert-butyl alcohol (TBA) and histidine (His) were utilized to scavenge $\mathrm{OH}$ and singlet oxygen $\left({ }^{1} \mathrm{O}_{2}\right)$, respectively. The detailed experimental procedures mentioned above can also be found in Table S4.

\subsection{Analytical Methods}

The phenol in aqueous solution was detected by UV-Vis spectrophotometry at a wavelength of $287.5 \mathrm{~nm}$ [49]. Briefly, a $3 \mathrm{~mL}$ sample was taken out periodically. After centrifugation, the sample was subjected to filtration with a pre-rinsed $0.45 \mu \mathrm{m}$ filter and then analyzed in a spectrophotometer. The indigo method [50] was used to determine the ozone concentration in aqueous solution. COD was measured following standard methods [48]. The $\mathrm{pH}$ was recorded by a $\mathrm{pH}$ meter (FE28-Standard, Mettler Toledo, Zurich, Switzerland). Flame atomic absorption spectrometry [51] was adopted to analyze iron and nickel that leached from the catalyst. The fluorescence excitation emission matrices (EEMs) were carried out on a Hitachi spectrofluorometer F-4600 (emission wavelength: 250-550 nm; excitation wavelength: $200-500 \mathrm{~nm}$; slit width: $5 \mathrm{~nm}$ ). 


\section{Conclusions}

A novel binary catalyst of Fe-Ni/MAC was synthesized by the co-precipitation method and the optimal preparation conditions were obtained by response surface methodology. Some conclusions can be drawn as follows:

(1) The optimal conditions for catalytic ozonation obtained by response surface methodology (RSM) were catalyst $10 \mathrm{~g} / \mathrm{L}$, ozone $68 \mathrm{mg} / \mathrm{L}, \mathrm{pH} 9$ and reaction time $90 \mathrm{~min}$.

(2) Despite being reused six times, Fe-Ni/MAC catalysts were stable in the catalytic process with excellent performance and no secondary pollution.

(3) The primary radical responsible for the degradation of phenol was proved to be $\cdot \mathrm{O}_{2}^{-}\left({ }^{1} \mathrm{O}_{2}\right)$, while other radicals played a minor role, based on radical scavenging experiments.

(4) The fluorescence excitation emission matrices (EEMs) indicated that as much as $1243 \mathrm{mg} / \mathrm{L}$ phenol in the real wastewater was completely degraded.

Overall, Fe-Ni/MAC might be an efficient and practical catalyst in the degradation of phenol.

Supplementary Materials: The following are available online at http://www.mdpi.com/2073-4344/10/10/1123/s1. Table S1: Factors and levels in RSM based on BBD, Table S2: Quality of the real phenol-containing wastewater, Table S3: Design and results of RSM based on BBD, Figure S1: Experimental system for the catalytic ozonation of phenol, Figure S2: Contour plots of phenol RE as a function of temperature and iron-nickel ratio (a), iron-nickel ratio and time (b) and temperature and time (c), Figure S3: Phenol removal by Fe-Ni/MAC synthesized under optimal conditions.

Author Contributions: Y.Y., writing_original draft; X.S., formal analysis; M.Z., project administration; S.C., supervision; J.X., methodology. All authors have read and agreed to the published version of the manuscript.

Funding: The authors gratefully acknowledge the Public Research Project of Zhejiang Province (LGF20E090001 and LGF19E090002) and the Basic Research Project of Wenzhou City (Z20160011).

Conflicts of Interest: The authors declare no conflict of interest.

\section{References}

1. Muhammad, S.; Saputra, E.; Sun, H.; Ang, H.-M.; Tadé, M.O.; Wang, S. Heterogeneous Catalytic Oxidation of Aqueous Phenol on Red Mud-Supported Cobalt Catalysts. Ind. Eng. Chem. Res. 2012, 51, 15351-15359. [CrossRef]

2. Dohnal, V.; Fenclova, D. Air-Water Partitioning and Aqueous Solubility of Phenols. J. Chem. Eng. Data 1995, 40, 478-483. [CrossRef]

3. Keith, L.; Telliard, W. ES\&T Special Report: Priority pollutants: I-a perspective view. Environ. Sci. Technol. 1979, 13, 416-423.

4. Huang, C.-P.; Huang, Y.-H. Comparison of catalytic decomposition of hydrogen peroxide and catalytic degradation of phenol by immobilized iron oxides. Appl. Catal. A Gen. 2008, 346, 140-148. [CrossRef]

5. Barrault, J.; Abdellaoui, M.; Bouchoule, C.; Majesté, A.; Tatibouët, J.M.; Louloudi, A.; Papayannakos, N.; Gangas, N.H. Catalytic wet peroxide oxidation over mixed (Al-Fe) pillared clays. Appl. Catal. B Environ. 2000, 27, L225-L230. [CrossRef]

6. Shukla, P.R.; Wang, S.; Sun, H.; Ang, H.M.; Tadé, M. Activated carbon supported cobalt catalysts for advanced oxidation of organic contaminants in aqueous solution. Appl. Catal. B Environ. 2010, 100, 529-534. [CrossRef]

7. Esplugas, S.; Giménez, J.; Contreras, S.; Pascual, E.; Rodríguez, M. Comparison of different advanced oxidation processes for phenol degradation. Water Res. 2002, 36, 1034-1042. [CrossRef]

8. Zhao, H.; Dong, Y.; Jiang, P.; Wang, G.; Zhang, J.; Zhang, C. $\mathrm{ZnAl}_{2} \mathrm{O}_{4}$ as a novel high-surface-area ozonation catalyst: One-step green synthesis, catalytic performance and mechanism. Chem. Eng. J. 2015, 260, 623-630. [CrossRef]

9. Ma, Z.; Zhu, L.; Lu, X.; Xing, S.; Wu, Y.; Gao, Y. Catalytic ozonation of p-nitrophenol over mesoporous Mn-Co-Fe oxide. Sep. Purif. Technol. 2014, 133, 357-364. [CrossRef]

10. Dadban Shahamat, Y.; Sadeghi, M.; Shahryari, A.; Okhovat, N.; Bahrami Asl, F.; Baneshi, M.M. Heterogeneous catalytic ozonation of 2,4-dinitrophenol in aqueous solution by magnetic carbonaceous nanocomposite: Catalytic activity and mechanism. Desalin. Water Treat. 2016, 57, 20447-20456. [CrossRef] 
11. Fajardo, A.S.; Martins, R.C.; Quinta-Ferreira, R.M. Treatment of a simulated phenolic effluent by heterogeneous catalytic ozonation using $\mathrm{Pt} / \mathrm{Al}_{2} \mathrm{O}_{3}$. Environ. Technol. 2013, 34, 301-311. [CrossRef] [PubMed]

12. Dong, Y.; Yang, H.; He, K.; Song, S.; Zhang, A. $\beta-\mathrm{MnO}_{2}$ nanowires: A novel ozonation catalyst for water treatment. Appl. Catal. B Environ. 2009, 85, 155-161. [CrossRef]

13. Wei, X.; Shao, S.; Ding, X.; Jiao, W.; Liu, Y. Degradation of phenol with heterogeneous catalytic ozonation enhanced by high gravity technology. J. Clean. Prod. 2020, 248, 119179. [CrossRef]

14. Shahamat, Y.D.; Farzadkia, M.; Nasseri, S.; Mahvi, A.H.; Gholami, M.; Esrafili, A. Magnetic heterogeneous catalytic ozonation: A new removal method for phenol in industrial wastewater. J. Environ. Health Sci. Eng. 2014, 12, 50. [CrossRef] [PubMed]

15. Farzadkia, M.; Dadban Shahamat, Y.; Nasseri, S.; Mahvi, A.H.; Gholami, M.; Shahryari, A. Catalytic Ozonation of Phenolic Wastewater: Identification and Toxicity of Intermediates. J. Eng. 2014, 2014, 520929. [CrossRef]

16. Aliyu, A.; Abdulkareem, A.S.; Kovo, A.S.; Abubakre, O.K.; Tijani, J.O.; Kariim, I. Synthesize multi-walled carbon nanotubes via catalytic chemical vapour deposition method on Fe-Ni bimetallic catalyst supported on kaolin. Carbon Lett. 2017, 21, 33-50. [CrossRef]

17. Hong, E.; Bang, S.; Cho, J.H.; Jung, K.D.; Shin, C.-H. Reductive amination of isopropanol to monoisopropylamine over $\mathrm{Ni}-\mathrm{Fe} / \gamma-\mathrm{Al}_{2} \mathrm{O}_{3}$ catalysts: Synergetic effect of $\mathrm{Ni}$-Fe alloy formation. Appl. Catal. A Gen. 2017, 542, 146-153. [CrossRef]

18. Zhang, Y.; Huang, J.; Williams, P.T. Fe-Ni-MCM-41 Catalysts for Hydrogen-Rich Syngas Production from Waste Plastics by Pyrolysis-Catalytic Steam Reforming. Energy Fuels 2017, 31, 8497-8504. [CrossRef]

19. Ni, S.-Q.; Yang, N. Cation exchange resin immobilized bimetallic nickel-iron nanoparticles to facilitate their application in pollutants degradation. J. Colloid Interface Sci. 2014, 420, 158-165. [CrossRef]

20. Tian, D.; Liu, Z.; Li, D.; Shi, H.; Pan, W.; Cheng, Y. Bimetallic Ni-Fe total-methanation catalyst for the production of substitute natural gas under high pressure. Fuel 2013, 104, 224-229. [CrossRef]

21. Hu, J.; Guo, Z.; Chu, W.; Li, L.; Lin, T. Carbon dioxide catalytic conversion to nano carbon material on the iron-nickel catalysts using CVD-IP method. J. Energy Chem. 2015, 24, 620-625. [CrossRef]

22. Wu, M.-S.; Jao, C.-Y.; Chuang, F.-Y.; Chen, F.-Y. Carbon-encapsulated nickel-iron nanoparticles supported on nickel foam as a catalyst electrode for urea electrolysis. Electrochim. Acta 2017, 227, 210-216. [CrossRef]

23. Singh, V.; Belova, L.; Singh, B.; Sharma, Y.C. Biodiesel production using a novel heterogeneous catalyst, magnesium zirconate $\left(\mathrm{Mg}_{2} \mathrm{Zr}_{5} \mathrm{O}_{12}\right)$ : Process optimization through response surface methodology (RSM). Energy Convers. Manag. 2018, 174, 198-207. [CrossRef]

24. Haider, M.; Pakshirajan, K. Screening and optimization of media constituents for enhancing lipolytic activity by a soil microorganism using statistically designed experiments. Appl. Biochem. Biotechnol. 2007, 141, 377-390. [CrossRef] [PubMed]

25. Abu Hasan, H.; Abdullah, S.R.S.; Kamarudin, S.K.; Kofli, N.T. Response surface methodology for optimization of simultaneous COD, NH4+-N and Mn2+ removal from drinking water by biological aerated filter. Desalination 2011, 275, 50-61. [CrossRef]

26. Coetzee, J.F. Recommended Methods for Purification of Solvents and Tests for Impurities, 1st ed.; Coetzee, J.F., Ed.; Pergamon: Oxford, UK, 1982; p. 68.

27. Kustov, A.L.; Frey, A.M.; Larsen, K.E.; Johannessen, T.; Nørskov, J.K.; Christensen, C.H. CO methanation over supported bimetallic Ni-Fe catalysts: From computational studies towards catalyst optimization. Appl. Catal. A Gen. 2007, 320, 98-104. [CrossRef]

28. Xu, F.; Deng, S.; Xu, J.; Zhang, W.; Wu, M.; Wang, B.; Huang, J.; Yu, G. Highly Active and Stable Ni-Fe Bimetal Prepared by Ball Milling for Catalytic Hydrodechlorination of 4-Chlorophenol. Environ. Sci. Technol. 2012, 46, 4576-4582. [CrossRef]

29. Zhang, H.; Ji, F.Z.; Zhang, Y.H.; Pan, Z.C.; Lai, B. Catalytic ozonation of N,N-dimethylacetamide (DMAC) in aqueous solution using nanoscaled magnetic $\mathrm{CuFe}_{2} \mathrm{O}_{4}$. Sep. Purif. Technol. 2018, 193, 368-377. [CrossRef]

30. Olszewska, D. Application of XPS method in the research into Ni ion-modified montmorillonite as a $\mathrm{SO}_{2}$ sorbent. Fuel Process. Technol. 2012, 95, 90-95. [CrossRef]

31. Wang, W.; Wang, Z.; Ding, Y.; Xi, J.; Lu, G. Partial Oxidation of Ethanol to Hydrogen over Ni-Fe Catalysts. Catal. Lett. 2002, 81, 63-68. [CrossRef]

32. Biesinger, M.C.; Payne, B.P.; Grosvenor, A.P.; Lau, L.W.M.; Gerson, A.R.; Smart, R.S.C. Resolving surface chemical states in XPS analysis of first row transition metals, oxides and hydroxides: $\mathrm{Cr}, \mathrm{Mn}, \mathrm{Fe}, \mathrm{Co}$ and $\mathrm{Ni}$. Appl. Surf. Sci. 2011, 257, 2717-2730. [CrossRef] 
33. Yamamoto, S.; Kendelewicz, T.; Newberg, J.T.; Ketteler, G.; Starr, D.E.; Mysak, E.R.; Andersson, K.J.; Ogasawara, H.; Bluhm, H.; Salmeron, M.; et al. Water Adsorption on $\alpha-\mathrm{Fe}_{2} \mathrm{O}_{3}(0001)$ at near Ambient Conditions. J. Phys. Chem. C 2010, 114, 2256-2266. [CrossRef]

34. Qi, F.; Chu, W.; Xu, B. Ozonation of phenacetin in associated with a magnetic catalyst $\mathrm{CuFe}_{2} \mathrm{O}_{4}$ : The reaction and transformation. Chem. Eng. J. 2015, 262, 552-562. [CrossRef]

35. Wu, J.; Gao, H.; Yao, S.; Chen, L.; Gao, Y.; Zhang, H. Degradation of Crystal Violet by catalytic ozonation using Fe/activated carbon catalyst. Sep. Purif. Technol. 2015, 147, 179-185. [CrossRef]

36. Pan, F.; Luo, Y.; Fan, J.-J.; Liu, D.-C.; Fu, J. Degradation of Disperse Blue E-4R in Aqueous Solution by Zero-Valent Iron/Ozone. Clean Soilairwater 2012, 40, 422-427. [CrossRef]

37. Chiang, H.-L.; Huang, C.P.; Chiang, P.C. The surface characteristics of activated carbon as affected by ozone and alkaline treatment. Chemosphere 2002, 47, 257-265. [CrossRef]

38. Valdés, H.; Sánchez-Polo, M.; Rivera-Utrilla, J.; Zaror, C.A. Effect of Ozone Treatment on Surface Properties of Activated Carbon. Langmuir 2002, 18, 2111-2116. [CrossRef]

39. Chiang, H.-L.; Chiang, P.C.; Huang, C.P. Ozonation of activated carbon and its effects on the adsorption of VOCs exemplified by methylethylketone and benzene. Chemosphere 2002, 47, 267-275. [CrossRef]

40. Rivera-Utrilla, J.; Sánchez-Polo, M.; Gómez-Serrano, V.; Álvarez, P.M.; Alvim-Ferraz, M.C.M.; Dias, J.M. Activated carbon modifications to enhance its water treatment applications. An overview. J. Hazard. Mater. 2011, 187, 1-23. [CrossRef]

41. Coble, P.G. Characterization of marine and terrestrial DOM in seawater using excitation-emission matrix spectroscopy. Mar. Chem. 1996, 51, 325-346. [CrossRef]

42. Herath, N.; Ohtani, Y. Color and phenolic compounds reduction of Kraft Pulp Mill effluent by ozonation with some pretreatments. Am. J. Sci. Ind. Res. 2011, 2, 798-806. [CrossRef]

43. Tu, Y.-J.; Njus, D.; Schlegel, H.B. A theoretical study of ascorbic acid oxidation and HOO/O ${ }_{2} \cdot$ radical scavenging. Org. Biomol. Chem. 2017, 15, 4417-4431. [CrossRef] [PubMed]

44. Zhao, L.; Ma, J.; Sun, Z.-Z. Oxidation products and pathway of ceramic honeycomb-catalyzed ozonation for the degradation of nitrobenzene in aqueous solution. Appl. Catal. B Environ. 2008, 79, 244-253. [CrossRef]

45. Wade, A.M.; Tucker, H.N. Antioxidant characteristics of L-histidine 11The work described in this manuscript was partially sponsored and funded by Cytos Pharmaceuticals, LLC. J. Nutr. Biochem. 1998, 9, 308-315. [CrossRef]

46. Zhao, H.; Dong, Y.; Wang, G.; Jiang, P.; Zhang, J.; Wu, L.; Li, K. Novel magnetically separable nanomaterials for heterogeneous catalytic ozonation of phenol pollutant: $\mathrm{NiFe}_{2} \mathrm{O}_{4}$ and their performances. Chem. Eng. J. 2013, 219, 295-302. [CrossRef]

47. Huang, Y.; Cui, C.; Zhang, D.; Li, L.; Pan, D. Heterogeneous catalytic ozonation of dibutyl phthalate in aqueous solution in the presence of iron-loaded activated carbon. Chemosphere 2015, 119, 295-301. [CrossRef]

48. APHA. Standard Methods for the Examination of Water and Wastewater, 21st ed.; American Public Health Association: Washington, DC, USA, 2005.

49. Zhang, Q.; Gao, L.; Guo, J. Effects of calcination on the photocatalytic properties of nanosized $\mathrm{TiO}_{2}$ powders prepared by TiCl4 hydrolysis. Appl. Catal. B Environ. 2000, 26, 207-215. [CrossRef]

50. Bader, H.; Hoigné, J. Determination of ozone in water by the indigo method. Water Res. 1981, 15, 449-456. [CrossRef]

51. Ghaedi, M.; Tavallali, H.; Shokrollahi, A.; Zahedi, M.; Montazerozohori, M.; Soylak, M. Flame atomic absorption spectrometric determination of zinc, nickel, iron and lead in different matrixes after solid phase extraction on sodium dodecyl sulfate (SDS)-coated alumina as their bis (2-hydroxyacetophenone)-1,3-propanediimine chelates. J. Hazard. Mater. 2009, 166, 1441-1448. [CrossRef]

(C) 2020 by the authors. Licensee MDPI, Basel, Switzerland. This article is an open access article distributed under the terms and conditions of the Creative Commons Attribution (CC BY) license (http://creativecommons.org/licenses/by/4.0/). 